Old Dominion University

ODU Digital Commons

OEAS Faculty Publications

Ocean, Earth \& Atmospheric Sciences

1991

\title{
Hydrogen Sulfide and Radon in and Over the Western North Atlantic Ocean
}

\author{
T.W.Andreae
}

Gregory A. Cutter

Old Dominion University, gcutter@odu.edu

N. Hussain

J. Radford-Knoery

M. O. Andreae

Follow this and additional works at: https://digitalcommons.odu.edu/oeas_fac_pubs

Part of the Atmospheric Sciences Commons, Inorganic Chemistry Commons, Oceanography Commons, and the Physical Chemistry Commons

\section{Repository Citation}

Andreae, T. W.; Cutter, Gregory A.; Hussain, N.; Radford-Knoery, J.; and Andreae, M. O., "Hydrogen Sulfide and Radon in and Over the Western North Atlantic Ocean" (1991). OEAS Faculty Publications. 188.

https://digitalcommons.odu.edu/oeas_fac_pubs/188

\section{Original Publication Citation}

Andreae, T., Cutter, G., Hussain, N., Radford-knoery, J., \& Andreae, M. (1991). Hydrogen sulfide and radon in and over the western North Atlantic Ocean. Journal of Geophysical Research: Atmospheres, 96(D10), 18753-18760. doi: 10.1029/91JD01628

This Article is brought to you for free and open access by the Ocean, Earth \& Atmospheric Sciences at ODU Digital Commons. It has been accepted for inclusion in OEAS Faculty Publications by an authorized administrator of ODU Digital Commons. For more information, please contact digitalcommons@odu.edu. 


\title{
Hydrogen Sulfide and Radon in and Over the Western North Atlantic Ocean
}

\author{
T. W. Andreae, ${ }^{1}$ G. A. Cutter, ${ }^{2}$ N. Hussain, ${ }^{3}$ \\ J. RADFORD-KNOERY, ${ }^{2}$ AND M. O. ANDREAE ${ }^{1}$
}

\begin{abstract}
Atmospheric measurements of radon and hydrogen sulfide, and seawater measurements of total sulfide, free sulfide, and carbonyl sulfide, were made on a cruise in the western North Atlantic Ocean (October 24 to November 9,1989 ). Measured values for ${ }^{222} \mathrm{Rn}$ ranged from 3 to $70 \mathrm{pCi} \mathrm{m}^{-3}$, those for atmospheric hydrogen sulfide from 1 to 85 parts per trillion, and those for dissolved total and free sulfide in seawater from 33 to $930 \mathrm{pmol} \mathrm{L}^{-1}$ and 0 to $73 \mathrm{pmol} \mathrm{L}^{-1}$, respectively. A positive correlation between ${ }_{2}^{222} \mathrm{Rn}$ and atmospheric $\mathrm{H}_{2} \mathrm{~S}$ was observed. Both ${ }^{222} \mathrm{Rn}$ and $\mathrm{H}_{2} \mathrm{~S}$ were high in air masses traced back to North America: Measurements in seawater showed that uncomplexed sulfides were approximately $13 \%$ of total sulfide at $2 \mathrm{~m}$ depth. Atmospheric $\mathrm{H}_{2} \mathrm{~S}$ and dissolved $\mathrm{H}_{2} \mathrm{~S}$ in seawater were usually not far from saturation equilibrium. Our results indicate that the ocean acted at some times as á source of atmospheric $\mathrm{H}_{2} \mathrm{~S}$ but more frequently as a sink. Hydrolysis of COS and atmospheric deposition of $\mathrm{H}_{2} \mathrm{~S}$ both may contribute to the budget of dissolved sulfide in seawater of the western North Atlantic Ocean. On a global scale the ocean/atmosphere exchange of $\mathrm{H}_{2} \mathrm{~S}$ appears to play a minor role in the atmospheric sulfur cycle.
\end{abstract}

\section{INTRODUCTION}

In early models of the global sulfur cycle the emission of $\mathrm{H}_{2} \mathrm{~S}$ from the oceans was assumed to play a major role in balancing the atmospheric sulfur' budget. The sulfur budgets of Eriksson [1963], Rabinson and Rabbins [1970], and Kellogg et al. [1972] inferred the emission flux of $\mathrm{H}_{2} \mathrm{~S}$ from the oceans from the difference between the global deposition flux of sulfur and the sum of the estimates of all other sources of sulfur to the atmosphere. The uncertainty associated with such an approach is reflected in the wide range of the resulting estimates, from $30 \mathrm{Tg} \mathrm{S}\left(\mathrm{H}_{2} \mathrm{~S}\right) \mathrm{yr}^{-1}$ [Robinson and Robbin's, 1970] to $170 \mathrm{Tg} \mathrm{S}\left(\mathrm{H}_{2} \mathrm{~S}\right) \mathrm{yr}^{-1}$ [Eriksson, 1963].

Subsequent models made allowance for the existence of other reduced sulfur species, such as dimethyl sulfide (DMS), as the vehicle for biogenic sulfur emission to the atmosphere [e.g., Friend, 1973; Graedel, 1979; Rodhe and Isaksen, 1980]. However, the paucity of data still resulted in great uncertainty regarding the emission flux of $\mathrm{H}_{2} \mathrm{~S}$ and other reduced sulfur species. Rodhe and Isaksen [1980, p. 7408] used a flux of $40 \mathrm{Tg} \mathrm{S}\left(\mathrm{H}_{2} \mathrm{~S}\right) \mathrm{yr}^{-1}$ in their model and obtained atmospheric $\mathrm{H}_{2} \mathrm{~S}$ concentrations significantly larger than the observed values available at that time. From this they concluded that the flux of $\mathrm{H}_{2} \mathrm{~S}$ and DMS together is "at most a few tens of Tg S yr ${ }^{-1}$." Graedel [1979], using the mean $\mathrm{H}_{2} \mathrm{~S}$ concentration of 34 parts per trillion (ppt) measured by Slatt et al. [1978] at low altitude over the Florida Everglades as representative of the remote marine "background" atmosphere, estimated a marine source of $15 \mathrm{Tg} \mathrm{S}$ $\left(\mathrm{H}_{2} \mathrm{~S}\right) \mathrm{yr}^{-1}$ on the basis of a photochemical model calculation.

However, later measurements of atmospheric $\mathrm{H}_{2} \mathrm{~S}$ over

\footnotetext{
${ }^{1}$ Department of Biogeochemistry, Max Planck Institute for Chemistry, Federal Republic of Germany.

${ }^{2}$ Department of Oceanography, Old Dominion University, Norfolk, Virginia.

${ }^{3}$ College of Marine Studies, University of Delaware, Newark.
}

Copyright 1991 by the American Geophysical Union.

Paper number 91JD01628.

0148-0227/91/91JD-01628\$05.00 the open oceans are not consistent with an oceanic source of $\mathrm{H}_{2} \mathrm{~S}$ of the magnitude indicated by these models. Herrmann and Jaeschke [1984] reported values ranging from 11 to 118 ppt over the Atlantic Ocean, Slatt et al. [1978] measured concentrations ranging from 5 to $50 \mathrm{ppt}$ at Barbados and Sal Island in the North Atlantic, and Delmas and Servant [1982] measured a mean concentration of $14 \mathrm{ppt}$ over the Gulf of Guinea, where the atmosphere may have been influenced by the adjacent tropical forest areas. On the basis of these atmospheric concentrations and of estimates of the photochemical lifetime of $\mathrm{H}_{2} \mathrm{~S}$ in the atmosphere, Andreae [1986, 1990] states that a flux of $3 \mathrm{Tg} \mathrm{S} \mathrm{yr}^{-1}$ may be a realistic estimate. The low $\mathrm{H}_{2} \mathrm{~S}$ concentrations observed in marine air, and the discovery of the importance of DMS in the sea-to-air transfer of biogenic sulfur, has shifted emphasis from $\mathrm{H}_{2} \mathrm{~S}$ to DMS as a major contributor to the global sulfur cycle [Andreae, 1986]. The global flux of this compound has been estimated to be $35 \mathrm{Tg} \mathrm{S} \mathrm{yr}^{-1}$ [Andreae, 1990].

More recent measurements of $\mathrm{H}_{2} \mathrm{~S}$ in the remote marine atmosphere show even lower values than the earlier studies. An average of $8.5 \mathrm{ppt}$ was measured in air originating over the central Atlantic during a transect of the eastern Caribbean [Saltzman and Cooper, 1988]. In attempts to directly measure the sea-ta-air flux of $\mathrm{H}_{2} \mathrm{~S}$ using a Teflon-lined floating chamber in the Bahamas, no emissions were detected. This corresponds to an upper flux limit of $0.3 \mathrm{mg} \mathrm{S}$ $\mathrm{m}^{-2} \mathrm{yr}^{-1}$ which, if extrapolated to the global ocean area, corresponds to an upper limit of $1 \mathrm{Tg} \mathrm{S}\left(\mathrm{H}_{2} \mathrm{~S}\right) \mathrm{yr}^{-1}$ for the marine source of $\mathrm{H}_{2} \mathrm{~S}$ [Saltzman and Cooper, 1988].

At present the role of the ocean as a source or sink for atmospheric $\mathrm{H}_{2} \mathrm{~S}$ remains controversial. However, the development of improved techniques for measuring $\mathrm{H}_{2} \mathrm{~S}$ in air [Cooper and Saltzman, 1987] and water [Cutter and Oatts, 1987] have now made possible the acquisition of more reliable data. In this paper we present the first simultaneous measurements of $\mathrm{H}_{2} \mathrm{~S}$ in air and seawater. These data provide us with the information necessary to calculate the direction and magnitude of the air/sea flux for $\mathrm{H}_{2} \mathrm{~S}$. In addition, using measurements of atmospheric radon and carbonyl sulfide in the surface waters, we examine the sources of $\mathrm{H}_{2} \mathrm{~S}$ in the atmosphere and the surface ocean. 


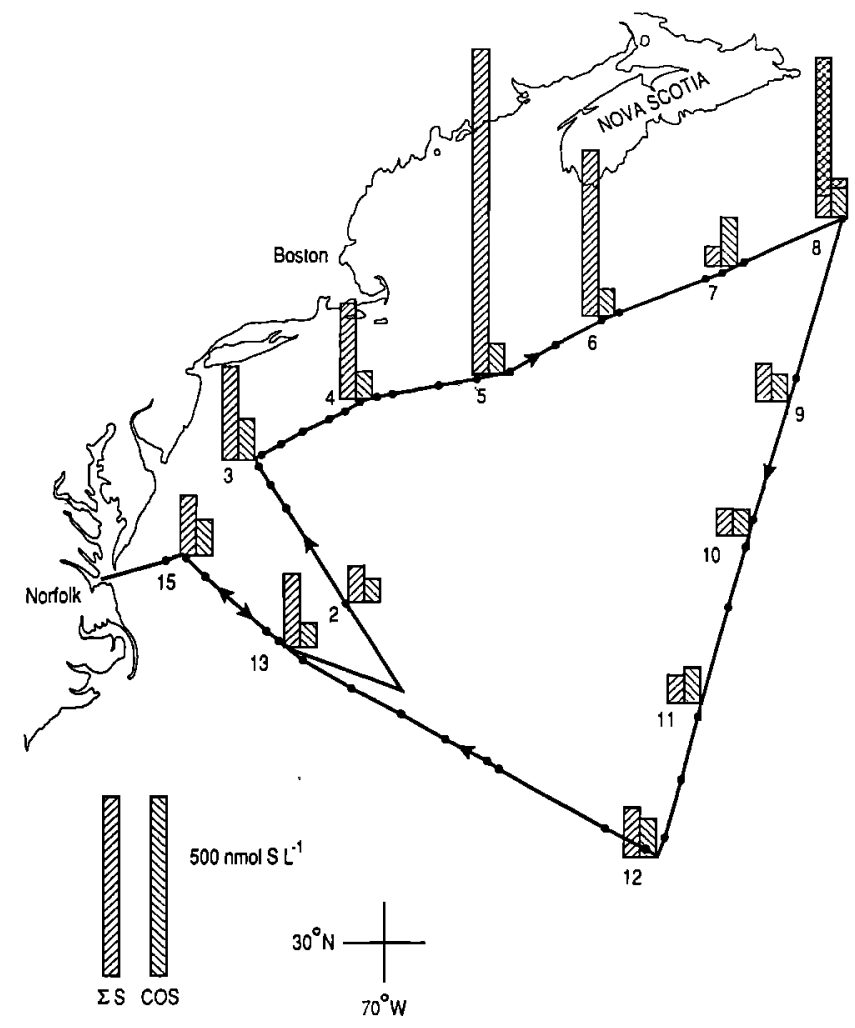

Fig. 1. Cruise track of the research vessel Cape Hatteras from October 24 to November 9,1989 . The stations are approximately 130 nautical miles apart; the ship's direction is shown by arrows along the cruise track. The location where each atmospheric $\mathrm{H}_{2} \mathrm{~S}$ sample was taken is indicated as a dot along the track. Concentrations of total sulfide ( $\Sigma S$, upwardly slashed bars) and carbonyl sulfide (COS, downwardly slashed bars) at a depth of $2 \mathrm{~m}$, as measured at each station, are shown. For station 8 , which was occupied for 25 hours, the range of values measured during a diel study is indicated.

\section{EXPERIMENT}

\subsection{Sampling Region and Cruise Logistics}

The Sulfide Experiment Cruise 2 began on October 24, 1989 as the RV Cape Hatteras set sail from the NOAA Atlantic Marine Facility Docks at Norfolk, Virginia. Its primary objective was to examine the sources and sinks of dissolved hydrogen sulfide in the oxygenated water column. A roughly triangular transect was followed from Norfolk along the shelf break to approximately $43^{\circ} \mathrm{N}, 56^{\circ} \mathrm{W}$, a position south of Sable Island, Nova Scotia, to Bermuda (U.S. Joint Global Ocean Flux Study (JGOFS) Time Series Station; $31^{\circ} 50^{\prime} \mathrm{N}, 64^{\circ} 10^{\prime} \mathrm{W}$ ) and back to Norfolk (Figure 1), where the cruise ended on November 9. Fifteen stations, each separated by approximately 130 nautical miles, were occupied. Samples from the upper $2 \mathrm{~m}$ of the water column were analyzed for dissolved and particulate sulfide, carbonyl sulfide, and ancillary parameters, such as dissolved oxygen and nutrients. Radon 222 and atmospheric hydrogen sulfide were measured around the clock (radon every $80 \mathrm{~min}$ and $\mathrm{H}_{2} \mathrm{~S}$ approximately every 4 hours) throughout the cruise.

\subsection{Sampling and Analytical Methods}

2.2.1. Determination of atmospheric ${ }^{222} \mathrm{Rn}$. Radon 222 decays with a half-life of 3.8 days through various short-lived daughter products to ${ }^{210} \mathrm{~Pb}\left(t_{1 / 2}=22.3\right.$ years $)$. At the time of emission into the atmosphere, ${ }^{222} \mathrm{Rn}$ is free of any daughter activity but reaches secular equilibrium with its daughters ${ }^{218} \mathrm{Po},{ }^{214} \mathrm{~Pb},{ }^{214} \mathrm{Bi}$, and ${ }^{214} \mathrm{Po}$ within hours. Once secular equilibrium is attained, it is possible to estimate the activity of ${ }^{222} \mathrm{Rn}$ by measuring the activity of the daughters.

Radon daughter products are electrically charged and chemically reactive. These nuclides are quickly bound to aerosol particles, mostly those in the size range of less than $0.25 \mu \mathrm{m}$. It has been shown that these particles are quantitatively collected by cellulose and glass fiber filters [Saunders et al., 1968]. Monitoring the beta activity of nuclides on the filter utilizing plastic scintillators then yields the ${ }^{222} \mathbf{R n}$ concentration of the air.

An automatic radon counter based on the design of Larson and Bressan [1978b] was used on the ship for continuous unattended operation. Briefly, the system consisted of a filter holder, a pump to draw a known quantity of air through the filter, a photomultiplier (PM) tube optically coupled to a plastic scintillator by silicon grease, and a scaler system to count the signal pulses. The plastic scintillator was covered with 0.05 -mm-thick aluminium foil to absorb alpha particles and provide a light shield to the PM tube. A high-voltage power supply provided dc power to the PM tube. Signals from the PM tube were shaped by a preamplifier and amplified. A discriminator then allowed signals above the background noise level to be counted by the scaler. The system containing its pump and filter holder was placed near the bridge.

The effective half-life of the short-lived radon daughter products is about $45 \mathrm{~min}$ at equilibrium. The air was drawn through the filter for $20 \mathrm{~min}$ and then counted for the next 20 min in two 10-min intervals. A further $20 \mathrm{~min}$ was allowed for the daughter nuclides to decay on the filter and counted again for $20 \mathrm{~min}$ in two 10-min intervals. After $80 \mathrm{~min}$ the next cycle was started. In this way, 18 observations of ${ }^{222} \mathrm{Rn}$ content in air were recorded per day. The filter was renewed every 24 hours, and appropriate background counts were recorded. Description of the counter calibration and data reduction calculations were made by Larson and Bressan [1978b].

2.2.2. Determination of atmospheric $\mathrm{H}_{2} \mathrm{~S}$. A sampling manifold, constructed of Teflon PFA and designed for duplicate sampling, was positioned on the bridge in a weatherprotected container. A sampling inlet of Teflon PFA tubing was extended from the manifold and positioned about two $\mathrm{m}$ forward of the bridge, well forward of potential contamination from personnel on the bridge, stack, galley, or sewage emissions. The inlet (12-mm-OD, PFA Teflon tubing) was shielded from moisture with Teflon housing. Samples were collected around the clock when the relative wind was between $270^{\circ}$ and $90^{\circ}$ of the bow. Special care was taken to obtain a sample just before arriving on and just after leaving a station, as conditions were often unfavorable for sampling while on station. Air was drawn through the filters at $10 \mathrm{~L}$ $\mathrm{min}^{-1}$; the normal sampling time was two hours.

Using the technique of Natusch et al. [1972] with the modification to correct for a COS artifact [Cooper and Saltzman, 1987], air was drawn over a pair of silver nitrate 
impregnated filters (Whatman 41, $47 \mathrm{~mm}$ diameter) each held in a Teflon PFA filter holder; the two holders were placed in series. The $\mathrm{H}_{2} \mathrm{~S}$ is retained on the filter as silver sulfide which was then extracted with a $0.1-\mathrm{M}$ sodium hydroxide/ sodium cyanide solution. Next, the sulfide was determined by the fluorescence quenching of dilute fluorescein mercuric acetate. The signal on the second filter in series represents a procedure blank. This blank is made up of traces of sulfide present in the filter and chemicals, sulfide adsorbed from the air during handling, and sulfide formed from the hydrolysis of atmospheric COS on the filters during sampling. This blank, which should be essentially the same on all filters of a given set, is subtracted from the signal on the front filter to yield the corrected concentration. Over the period of the cruise this correction ranged from 2 to 7 ppt. A Turner Designs, Model 10, fluorometer was used fitted with a blue lamp and 500-nm excitation, 520-nm emission filters each with $10-\mathrm{nm}$ band pass. Calibration in the field is accomplished using freshly prepared standard solutions of sodium sulfide [Natusch et al., 1972] which have been cross calibrated in the laboratory against solutions of anhydrous sodium sulfide (Alfa Research Chemicals, Karlsruhe, Germany, catalog number 65122) and certified permeation devices (VICI Metronics, Santa Clara, California). Over the range of values of concentrations encountered during the cruise the precision $(1 \sigma)$ is \pm 2 ppt or $15 \%$, whichever is greater. On the basis of the standard deviation of the blank, the detection limit ( $2 \sigma)$ of $2.5 \mathrm{ppt}$ is obtained. This method has been recently subjected to a rigorous intercomparison exercise (CITE-3, August/September 1989) and has been shown to be accurate to within $20 \%$ [Gregory et al., 1990; (G. L. Gregory et al., An intercomparison of instrumentation for tropospheric measurements of hydrogen sulfide: Aircraft results for concentrations at the parts-per-trillion level, submitted to Journal of Geophysical Research (1991)].

2.2.3. Determination of COS and sulfide in seawater. Seawater samples ( $2 \mathrm{~m}$ depth) were taken with Go-Flo bottles deployed on a conductivity, temperature, and depth (CTD)/rosette sampling system. Previous work [Johnson and Harrison, 1986] has indicated that sampling bottles can contribute COS contamination. Therefore the Go-Flos were thoroughly cleaned (Micro detergent wash, 1 day soak in $0.5-\mathrm{M} \mathrm{HCL}$, followed by deionized water) and then checked for $\mathrm{COS}$ and $\mathrm{H}_{2} \mathrm{~S}$ contamination. This involved filling the bottles with deionized water and analyzing aliquots of this water after 2, 4, and 24 hours for $\mathrm{H}_{2} \mathrm{~S}$ and $\mathrm{COS}$ (as described below). In addition, at some of the first stations, duplicate sampling bottles were filled with seawater and the COS and $\mathrm{H}_{2} \mathrm{~S}$ concentrations in each bottle compared. Several Go-Flo bottles, especially older bottles which had been repaired using polyvinyl chloride cement, were found to be highly contaminating and contributed up to $2 \mathrm{nmol} \mathrm{L}-1$ of $\mathrm{COS}$ or $\mathrm{H}_{2} \mathrm{~S}$ (i.e., a factor of 10 higher than typical surface water concentrations). Only Go-Flos which showed no contamination based on these procedures were used to obtain seawater samples.

In order to avoid contamination from the atmosphere after the sampling bottles came on deck, the Go-Flos were pressurized with $0.07 \mathrm{~atm}$ nitrogen, and the unfiltered water sample was pushed through polyethylene tubing into a transfer container ( $4 \mathrm{~L}$ polyethylene bottle with tubulation). When full, the container was brought into the ship's laboratory for the determination of hydrogen sulfide and carbonyl sulfide. Carbonyl sulfide was determined by hermetically transferring $300 \mathrm{~mL}$ of sample into a glass stripping vessel. COS was then stripped from solution with helium and cryogenically trapped using a glass U-tube filled with silanized glass wool and immersed in liquid nitrogen. The liquid nitrogen trap was connected to a six-way valve (Valco) which interfaced the stripping system (ambient pressure) with a gas chromatograph (pressure of $2.7 \mathrm{~atm}$ ). After $20 \mathrm{~min}$ of strip/trap time the trap was removed from the liquid nitrogen, and the COS was revolatilized and swept into a gas chromatograph (Hewlett Packard Model 5890) equipped with a 1.2-m Porapak QS column (acetone washed, de Souza et al. [1975]) and a flame photometric detector. The system was calibrated using a permeation device (VICI Metronics); the detection limit was $20 \mathrm{pmol} \mathrm{L}^{-1}$ as COS, and precision (as relative standard deviation (RSD)) was $10 \%$.

The concentration of total sulfide was determined using the method of Cutter and Oatts [1987]. Briefly, sulfide was reacted with zinc acetate to produce zinc sulfide, which was then immediately filtered $(0.4 \mu \mathrm{m})$ under a nitrogen atmosphere. The filter was placed in a glass stripping vessel along with deionized water. Upon acidification, $\mathrm{H}_{2} \mathrm{~S}$ was liberated and quantified using the gas chromatographic procedure described below. The detection limit for the zinc sulfide procedure was $5.5 \mathrm{pmol} \mathrm{S} \mathrm{L}^{-1}$, and the precision was $10 \%$. Total sulfide was also determined on board ship using a method similar to that described by Cutter and Krahforst [1988]. For this method, $300 \mathrm{~mL}$ seawater from the transfer container was placed in a helium-purged, stripping vessel equivalent to that used for COS. The sample was acidified with $\mathrm{HCl}$ to $p \mathrm{H} 3$, and the evolved $\mathrm{H}_{2} \mathrm{~S}$ cryogenically trapped. After revolatilization the $\mathrm{H}_{2} \mathrm{~S}$ was chromatographed on a 2-m Porapak QS column (acetone washed [de Souza et al., 1975]; continuously conditioned with $\mathrm{H}_{2} \mathrm{~S}$ from a permeation device in the carrier gas line) and detected via photoionization. The detection limit for the direct determination of sulfide was $\mathbf{0 . 5}$ pmol L ${ }^{-1}$, with a precision of $10 \%$ (RSD). The direct and zinc sulfide methods give comparable concentrations when used on the same samples [Cutter and Krahforst, 1988].

It is important to recognize that both methods determine total sulfide in a sample but cannot distinguish between free hydrogen sulfide $\left(\mathrm{H}_{2} \mathrm{~S}\right)$ and bisulfide $\left(\mathrm{HS}^{-}\right)$on one hand and sulfide ions complexed with metals (which liberate $\mathrm{H}_{2} \mathrm{~S}$ when acidified) on the other. In order to estimate the fraction of the total sulfide which might exist as hydrogen sulfide plus bisulfide ("free sulfide"), $\mathrm{H}_{2} \mathrm{~S}$ was purged from solution without acidification (i.e., using the COS method). The purged $\mathrm{H}_{2} \mathrm{~S}$ was then chromatographed and detected with the COS apparatus (i.e., flame photometric detection). Detection limits and precision for the free sulfide determinations are $15 \mathrm{pmol} \mathrm{L}^{-1}$ and $10 \%$ (RSD), respectively. We assume that metal sulfide complexes are kinetically stable [Luther and Tsamakis, 1989] and do not break down to produce $\mathrm{H}_{2} \mathrm{~S}$ during the $20 \mathrm{~min}$ of unacidified purging and trapping. However, we recognize that this is an operational definition, and the data which result should be interpreted with this limitation in mind.

\section{Results and Discussion}

\subsection{Radon and Atmospheric $\mathrm{H}_{2} \mathrm{~S}$}

The difference in ${ }^{222} \mathrm{Rn}$ source strengths between the continents and the oceans make it an ideal marker for air 


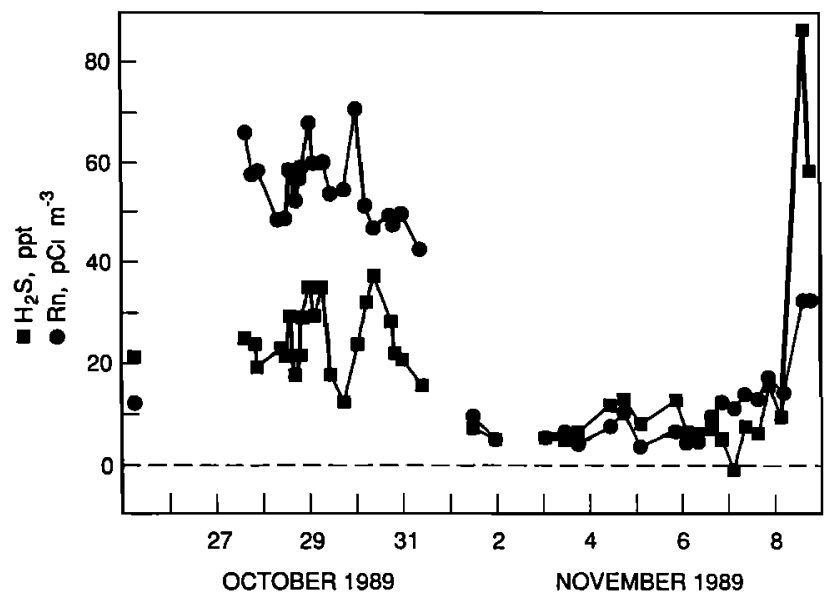

Fig. 2. Concentrations of ${ }^{222} \mathrm{Rn}$ and $\mathrm{H}_{2} \mathrm{~S}$ in the atmosphere along the cruise track. For $\mathrm{H}_{2} \mathrm{~S}$ each point represents the average of a pair of samples taken simultaneously. The error bars (not shown) are not larger than the symbols. The radon points are single values.

masses, and we, along with other authors [Andreae et al., 1988; Bressan et al., 1973; Brost and Chatfield, 1989; Doerr et al., 1983; Larson and Bressan, 1978a; Polian et al., 1986], have made use of this to identify air masses as being of continental or oceanic origin. Radon 222 concentrations in continental air masses are generally 1-2 orders of magnitude higher than in marine air masses. The radioactive decay of ${ }^{226} \mathrm{Ra}$ continuously produces ${ }^{222} \mathrm{Rn}$ gas which escapes into the atmosphere by processes such as diffusion from soil, plant transpiration, and degassing of groundwater. Other parameters, such as atmospheric pressure change during frontal movements and soil moisture content, also affect the ${ }^{222} \mathrm{Rn}$ emanation rates into the atmosphere [Tanner, 1978; Mogro-campero and Fleischer, 1978]. Typical continental concentrations for ${ }^{222} \mathrm{Rn}$ at ground level are of the order of $80-200 \mathrm{pCi} \mathrm{m}^{-3}$ [Lambert et al., 1982], while concentrations over the North Atlantic and Pacific are $2-3 \mathrm{pCi} \mathrm{m}^{-3}$ [Larson and Bressan, 1978a]. Radon measurements from Antarctic and sub-Antarctic areas give values as low as $0.1-2 \mathrm{pCi} \mathrm{m}^{-3}$, with similar values being reported for the South Pacific [Polian et al., 1986; Larson and Bressan, 1978a]. The similarity between the residence time of $\mathrm{H}_{2} \mathrm{~S}$ in the marine lower troposphere (approximately 2 days [Sze and $K o, 1980$; Toon et al., 1987]) and the half-life of radon (3.8 days) makes radon a useful tracer for atmospheric $\mathrm{H}_{2} \mathrm{~S}$ of continental origin.

Radon concentrations of $40-70 \mathrm{pCi} \mathrm{m}^{-3}$, indicative of continentally influenced air [Larson and Bressan, 1978a], were observed during the first part of the cruise (October 25-31, Figure 2) after which they dropped to $3-10 \mathrm{pCi} \mathrm{m}^{-3}$, indicative of remote North Atlantic air [Larson and Bressan, 1978a]. The radon concentration began to rise again as the ship approached the coast on November 8. Atmospheric $\mathrm{H}_{2} \mathrm{~S}$ concentrations were between 10 and $40 \mathrm{ppt}$ for the same period that radon was elevated and dropped to less than 10 ppt coincidentally with the drop in radon (Figure 2). Similar to radon, $\mathrm{H}_{2} \mathrm{~S}$ began to rise again as the ship approached shore. Although the concentration of radon measured during the cruise did fall as low as $3 \mathrm{pCi} \mathrm{m}^{-3}$, such low levels were only reached on November 2,3,4, and 6. During most of the cruise they remained at higher levels, indicating that the air
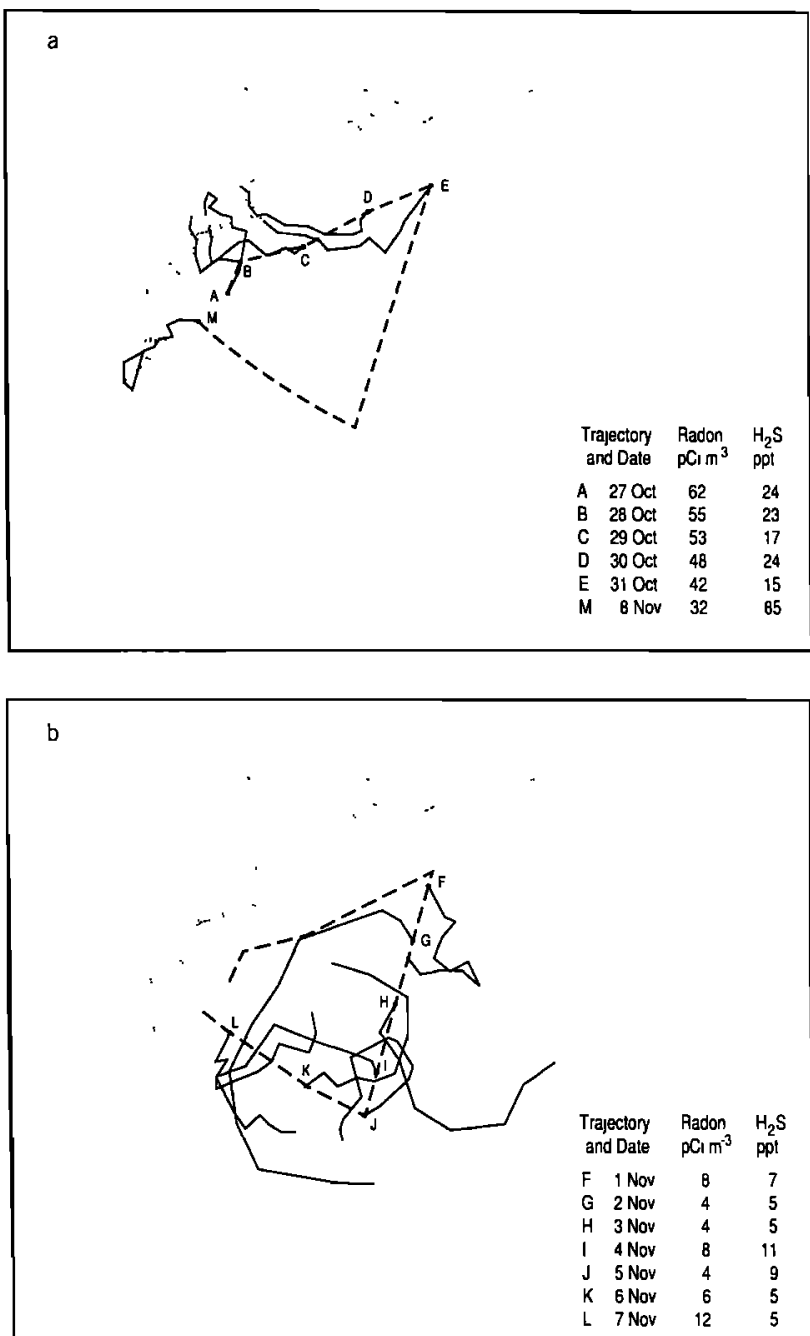

Fig. 3. (a) Three day back-trajectories, showing continentally influenced air masses which had come from land within 3 days and where $\mathrm{Rn}$ and $\mathrm{H}_{2} \mathrm{~S}$ were elevated, and (b) marine air masses (which had been over the ocean for the previous 3 days) with low $\mathrm{Rn}$ and $\mathrm{H}_{2} \mathrm{~S}$ levels. Seventy-two-hour back trajectories were calculated for each 24-hour period during the cruise, each starting at 1500 UT.

sampled had some continental influence. In summary, radon and $\mathrm{H}_{2} \mathrm{~S}$ covaried with few exceptions during the cruise, and elevated $\mathrm{H}_{2} \mathrm{~S}$ concentrations were never observed when radon was at low, marine levels. This suggests that $\mathrm{H}_{2} \mathrm{~S}$ over the North Atlantic Ocean, even quite far from land, is primarily of continental origin.

To further strengthen our argument we have calculated isobaric back trajectories on the basis of the winds interpolated from the pressure gradient pattern on the surface maps from the Deutscher Wetterdienst in Offenbach, Germany. The ship's position every 24 hours at 1500 UT was used as the starting point for each trajectory. The air mass was followed backward in time at 6 hourly intervals for a total time of 72 hours, and its track was plotted on a chart (Figures $3 a$ and $3 b$ ). From the beginning of the cruise until station 8 (Figures 1 and 2), radon and $\mathrm{H}_{2} \mathrm{~S}$ levels were relatively high, with radon ranging from 62 to $32 \mathrm{pCi} \mathrm{m}^{-3}$ and $\mathrm{H}_{2} \mathrm{~S}$ ranging from 24 to $15 \mathrm{ppt}$ (Figure $3 a$ ). The back trajectories show that in all cases the air mass sampled had been over the eastern United States within the previous 3 days. There was 
a distinct change in air mass as we left station 8 and began the transect toward Bermuda. Radon and $\mathrm{H}_{2} \mathrm{~S}$ levels dropped to close to remote marine levels. Throughout the transect to Bermuda and continuing along with the cruise track back toward Norfolk, we remained in air masses which were clearly marine. The back trajectories, shown in Figure $3 b$, show that the air masses sampled had been over the ocean for at least 3 days previous to sampling; radon values were low, ranging from 12 to $8 \mathrm{pCi} \mathrm{m}^{-3}$ and $\mathrm{H}_{2} \mathrm{~S}$, also low, from 11 to $5 \mathrm{ppt}$. Trajectory $\mathrm{M}$ (Figure $3 a$ ) pertains to the last day before returning to port. It shows that the air mass had been over coastal regions up to approximately 24 hours before our samples were taken. Correspondingly, radon and $\mathrm{H}_{2} \mathrm{~S}$ values were high ( $32 \mathrm{pCi} \mathrm{m}{ }^{-3}$ and $85 \mathrm{ppt}$, respectively).

\subsection{Surface Layer $\mathrm{H}_{2} \mathrm{~S}$ and Air/Sea Flux}

3.2.1. Concentration of $\mathrm{H}_{2} \mathrm{~S}$ in water and air. Total sulfide in surface waters $(2 \mathrm{~m}$ depth) was determined at 13 stations along the cruise track (Figure 1). Substantial variations are apparent, with total sulfide concentrations near the shelf break (average of 370 pmol L $\mathrm{L}^{-1}, n=7$ ) over 3 times higher than those in the Sargasso Sea (average of 110 pmol $\mathrm{L}^{-1}, n=6$ ). In addition to its spatial variability, total sulfide also displayed temporal variations similar to those reported by Cutter and Krahforst [1988]. At station 8 (Figure 1), which was occupied for 25 hours in order to do a diel study, total sulfide ranged from 68 to $458 \mathrm{pmol} \mathrm{L}^{-1}$, with the highest concentrations found just prior to sunrise. In addition to total sulfide, "free" sulfide $\left(\mathrm{H}_{2} \mathrm{~S}+\mathrm{HS}^{-}\right.$as described above) was determined at stations $8,12,13$, and 15 . Concentrations of free sulfide at $2 \mathrm{~m}$ varied from nondetectable to 73 pmol L $\mathrm{L}^{-1}$ at these stations. Like total sulfide, free sulfide also displayed substantial temporal variability, and maximum free sulfide concentrations were found just prior to sunrise. Throughout the mixed layer, free sulfide averaged $14 \%$ of the total sulfide at the four stations. For our further calculations we will use the average free sulfide fraction obtained from the samples taken at $2 \mathrm{~m}$ depth (13\%).

In order to calculate $\mathrm{H}_{2} \mathrm{~S}$ fluxes across the air-sea interface, the concentrations of undissociated $\mathrm{H}_{2} \mathrm{~S}$ in surface waters must be calculated using thermodynamic constants and measured concentrations of total sulfide and "free" sulfide. $\mathrm{H}_{2} \mathrm{~S}$ has two dissociation constants, $p K_{1}$ and $p K_{2}$. In our calculations, instead of the ideal constant $p K_{1}$, we use the conditional dissociation constant $p K_{1}{ }^{*}$ which is adjusted for the in situ salinity and temperature. Here $p K_{1}{ }^{*}$ was calculated according to the equation

$$
p K_{1}^{*}=p K_{1}+A S^{1 / 2}+B S,
$$

where

$$
p K_{1}=-98.080+5765.4 / T+15.0455 \ln T,
$$

$S$ is salinity, $A=0.0057-19.98 / T, B=0.0028$, and $T$ is in Kelvin [Millero and Hershey, 1989]. These $p K_{1}{ }^{*}$ values, and the value of $p K_{2}=1.00 \times 10^{-13}$, were used to calculate the concentration of undissociated, dissolved $\mathrm{H}_{2} \mathrm{~S}$ according to Stumm and Morgan [1981]:

$$
\left(\mathrm{H}_{2} \mathrm{~S}\right)_{\text {liq }}=\frac{\sum(\mathrm{S})}{1+K_{1} /\left[H^{+}\right]+K_{1} K_{2} /\left[\mathrm{H}^{+}\right]^{2}} .
$$

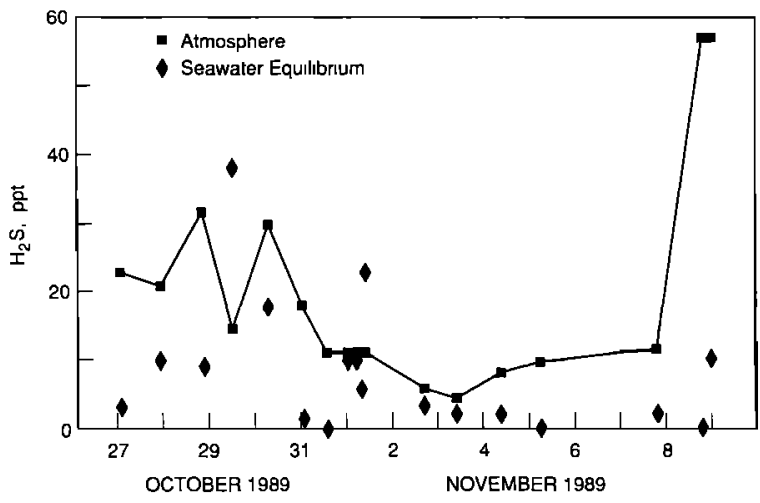

Fig. 4a. Comparison of calculated equilibrium gas phase $\mathrm{H}_{2} \mathrm{~S}$ and directly measured atmospheric $\mathrm{H}_{2} \mathrm{~S}$. The atmospheric samples taken closest in time to the water samples are used for this comparison. Remote marine levels of atmospheric $\mathrm{H}_{2} \mathrm{~S}$ were observed from October 13 to November 7, 1989.

In this equation, $\Sigma(S)$ is the free sulfide, that is, the sum of dissolved $\mathrm{H}_{2} \mathrm{~S}, \mathrm{HS}^{-}$, and $\mathrm{S}^{2-}$, which was measured directly or, in the cases where direct measurement was not possible, estimated to be $13 \%$ of the measured total sulfide (see above). Seawater $p H$ was assumed to be 8.3 (therefore the concentration of $\mathrm{H}^{+}$is $5.01 \times 10^{-9}$ ).

We derived the dimensionless Henry's law constant $(H)$ for hydrogen sulfide:

$$
H=1 / K_{H} R T \text {. }
$$

The seawater temperature during the cruise varied from $14^{\circ}$ to $25^{\circ} \mathrm{C}$. The solubility of hydrogen sulfide, $K_{H}$, at ambient temperature and salinity has been taken from Douabul and Riley [1979]. The resulting value of $H$ for our cruise ranges from 0.35 to 0.41 , depending on ambient temperature and salinity. These calculated values compare well to other values in the literature. At a temperature of $20^{\circ} \mathrm{C}$, the Henry's law constant is given as 0.35 [Elliott and Rowland, 1990]; at $25^{\circ} \mathrm{C}, H$ is given as 0.4 [Stumm and Morgan, 1983].

We then obtain the gas phase concentration in equilibrium with the concentration of dissolved $\mathrm{H}_{2} \mathrm{~S}$, using the above calculated $\left(\mathrm{H}_{2} \mathrm{~S}\right)_{\mathrm{liq}}$ and Henry's law constant:

$$
\left(\mathrm{H}_{2} \mathrm{~S}\right)_{\text {gas }}=\left(\mathrm{H}_{2} \mathrm{~S}\right)_{\text {liq }} / \mathrm{H} \text {. }
$$

The $\mathrm{H}_{2} \mathrm{~S}$ equilibrium gas phase values thus calculated and converted to parts per trillion can be compared with the measured atmospheric $\mathrm{H}_{2} \mathrm{~S}$ values (Figure $4 a$ ). In all but two cases the equilibrium gas phase values are lower than the atmospheric values, indicating that $\mathrm{H}_{2} \mathrm{~S}$ in the surface seawater is undersaturated with respect to the atmosphere.

3.2.2. $\mathrm{H}_{2} \mathrm{~S}$ flux. To calculate the $\mathrm{H}_{2} \mathrm{~S}$ flux for the samples taken during the cruise period, we have followed the approach of Balls and Liss [1983], where the transfer of a gas across the gas-liquid interface (the flux $F$ ) is proportional to the difference in concentration of the gas between the two phases $(\Delta C)$. For gases which undergo dissociation in aqueous solution the concentration of the undissociated species (in this case undissociated, dissolved $\mathrm{H}_{2} \mathrm{~S}$ ) must be used in the computation of $\Delta C$. The constant of proportionality is the overall transfer velocity $\left(K_{1}\right)$, expressed as a liquid phase 


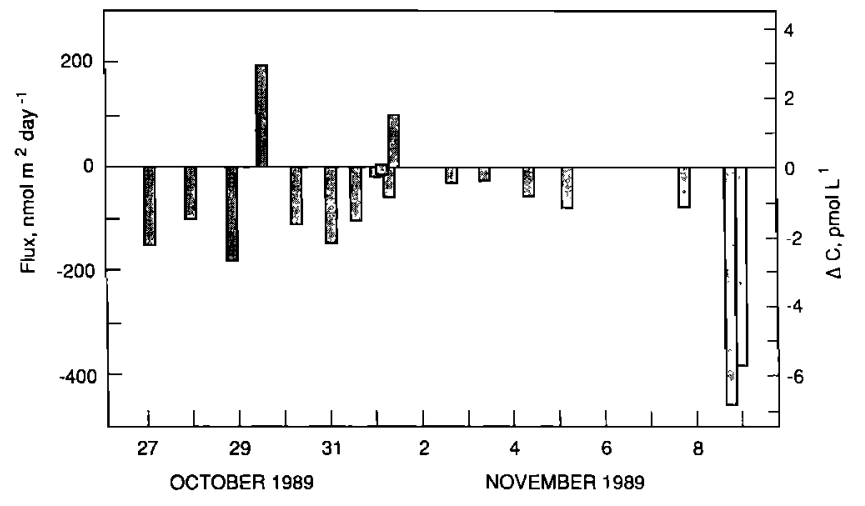

Fig. $4 b . \mathrm{H}_{2} \mathrm{~S}$ flux along the cruise track. On the right side, $\Delta C=$ $\left(\mathrm{H}_{2} \mathrm{~S}\right)_{\text {water }}-\left(\mathrm{H}_{2} \mathrm{~S}\right)_{\text {air }}$ is indicated. Upward fluxes (ocean to atmosphere) are shown as positive values.

concentration. $F$ has the units of $n m o l \mathrm{~m}^{-2} \mathrm{~d}^{-1}$ and $\Delta C$ that of nmol $\mathrm{m}^{-3}$. Thus

$$
F=K_{1} \Delta C,
$$

where

$$
\Delta C=\left(\mathrm{H}_{2} \mathrm{~S}\right)_{\text {water }}-\left(\mathrm{H}_{2} \mathrm{~S}\right)_{\text {air }}
$$

The concentration of $\mathrm{H}_{2} \mathrm{~S}$ in air was directly measured, as described in the methods section, and the concentration of undissociated $\mathrm{H}_{2} \mathrm{~S}$ in water was calculated as described in section 3.2.1. $K_{1}$ was calculated as follows:

$$
\frac{1}{K_{1}}=\frac{1}{\alpha k_{1}}+\frac{1}{H k_{g}},
$$

where $\alpha$ is the chemical enhancement factor which takes into account the reduced liquid phase resistance due to the dissociation of $\mathrm{H}_{2} \mathrm{~S}$. Typical values for $k_{1}$ and $k_{g}$ are $20 \mathrm{~cm}$ $\mathrm{h}^{-1}$ and $3000 \mathrm{~cm} \mathrm{~h}^{-1}$, respectively [Liss and Slater, 1974]. While it is well known that these constants are dependent on wind speed [Liss and Merlivat, 1986], we feel that the data currently available do not justify inclusion of the wind speed dependence in our calculations. The Henry's law constant $H$ was calculated as discussed in the previous section.

The chemical enhancement factor $\alpha$ can be predicted theoretically. We, as Balls and Liss [1983], have used the equation of Hoover and Berkshire [1969]:

$$
\begin{aligned}
\alpha=\left[\tau\left(k^{*} \tau / D\right)^{1 / 2}\left(D / k_{1}\right)\right] & \left\{(\tau-1)\left(k^{*} \tau / D\right)^{1 / 2}\left(D / k_{1}\right)\right. \\
+ & \left.\tanh \left[\left(k^{*} \tau / D\right)^{1 / 2}\left(D / k_{1}\right)\right]\right\},
\end{aligned}
$$

where $k^{*}$ and $D$ are the hydration rate constant and the coefficient of molecular diffusion of the gas in seawater, and $\tau$ is the ratio of total to ionic forms of the dissolved gas in the water.

To simplify this equation, we define $A$, which is unitless:

$$
A=\left(k^{*} \tau / D\right)^{1 / 2}\left(D / k_{1}\right) \text {. }
$$

Over the applicable range of parameters, the term

$$
\tanh \left(k^{*} \tau / D\right)^{1 / 2}\left(D / k_{1}\right)
$$

is not significantly different from 1 . Finally, $\tau$ is equal to the total amount of dissolved sulfide $\left(\mathrm{H}_{2} \mathrm{~S}+\mathrm{HS}^{-}+\mathrm{S}^{2-}\right)$ divided by the amount of ionized sulfide $\left(\mathrm{HS}^{-}+\mathrm{S}^{2-}\right)$ in the water. Therefore making the substitutions, $\alpha$ becomes

$$
\alpha=\frac{\tau A}{(\tau-1) A+1} .
$$

To calculate $A$ we need to know $\tau, D, k^{*}$, and $k_{1}$. The average value of $\tau$ for our data set is 1.034 . $D$, the coefficient of molecular diffusion of $\mathrm{H}_{2} \mathrm{~S}$ in seawater, is equal to $1.56 \times$ $10^{-5} \mathrm{~cm}^{2} \mathrm{~s}^{-1}$ [Broecker and Peng, 1974], and $k^{*}$, the hydration rate constant for $\mathrm{H}_{2} \mathrm{~S}$, is equal to $4.3 \times 10^{3} \mathrm{~s}^{-1}$ [Eigen et al. 1964].

After making the substitutions we arrive at a value for $\alpha$, for the parameters of this data set, of 18.6 (dimensionless). Using this value and going back to (8), we calculate the overall transfer velocity $K_{1}$ equal to $285 \mathrm{~cm} \mathrm{~h}^{-1}$.

We now make the flux calculations using (6). The flux varied from -450 to $+190 \mathrm{nmol} \mathrm{m}^{-2} \mathrm{~d}^{-1}$ (negative values correspond to downward fluxes). The flux had an upward direction on only two occasions $\left(100\right.$ and $\left.190 \mathrm{nmol} \mathrm{m}^{-2} \mathrm{~d}^{-1}\right)$. The overall average $\mathrm{H}_{2} \mathrm{~S}$ flux was $-83 \mathrm{nmol} \mathrm{m}^{-2} \mathrm{~d}^{-1}$ (Figure $4 b$ ), indicating that in the ocean region sampled during the cruise the overall direction for $\mathrm{H}_{2} \mathrm{~S}$ transport was from the air into the sea. From October 31 to November 7, during which time remote marine levels of atmospheric $\mathrm{H}_{2} \mathrm{~S}$ were observed ( $\leq 12 \mathrm{ppt}$ ), the flux ranged from -90 to $+99 \mathrm{nmol}$ $\mathrm{m}^{-2} \mathrm{~d}^{-1}$ and had an average of $-25 \mathrm{nmol} \mathrm{m} \mathrm{m}^{-2} \mathrm{~d}^{-1}$

Taking our average flux of $-83 \mathrm{nmol} \mathrm{m} \mathrm{m}^{-2}$ as representative for the western North Atlantic Ocean, and using the area of $2.3 \times 10^{12} \mathrm{~m}^{2}$ given by Galloway and Whelpdale [1987], the air-sea transfer of $\mathrm{H}_{2} \mathrm{~S}$ represents a sink of 0.0022 $\operatorname{Tg~S~} \mathrm{yr}^{-1}$. Thus, at least in this region, marine emissions of $\mathrm{H}_{2} \mathrm{~S}$ do not contribute to the atmospheric sulfur cycle. To put the magnitude of this flux in perspective, we can compare it to the source flux of DMS for this region and the input of anthropogenic sulfur into the West North Atlantic Ocean atmosphere which have been estimated at 0.1 and $2-4 \mathrm{Tg} \mathrm{S}$ $\mathrm{yr}^{-1}$, respectively [Berresheim et al., 1991; Galloway and Whelpdale, 1987]. We conclude that for the atmospheric sulfur budget, $\mathrm{H}_{2} \mathrm{~S}$ fluxes are miniscule compared with those of other sulfur compounds in this region.

However, the observed downward flux of $\mathrm{H}_{2} \mathrm{~S}$ implies that atmospheric deposition is a source for $\mathrm{H}_{2} \mathrm{~S}$ in the surface waters of the western North Atlantic Ocean. The magnitude of this source term can be compared to another source of sulfide in surface waters, the hydrolysis of COS [Elliott et al., 1987]. In contrast to total sulfide, $\operatorname{COS}$ at $2 \mathrm{~m}$ (Figure 1) displays little spatial variation, averaging $96 \mathrm{pmol} \mathrm{L}^{-1}(n=$ 7) near the shelf break and 75 pmol L-1 $(n=6)$ in the Sargasso Sea. Furthermore, the diel variations in COS are minor (e.g., $90-114$ pmol L ${ }^{-1}$ at station 8 ), with the highest concentrations found in the late afternoon. To assess the contribution of COS hydrolysis to the observed sulfide distributions in surface waters, the model proposed by Elliott et al. [1987] is utilized. In this model, sulfide is produced via COS hydrolysis (rate constants reported by Elliott et al. [1989]) and consumed by oxidation (rate constants reported by Millero and Hershey [1989]). As a result, concentrations of total sulfide should be similar to those of COS (i.e., approximately 100 pmol $\mathrm{L}^{-1}$ ). In the Sargasso Sea (stations 9-13, Figure 1), $\mathrm{H}_{2} \mathrm{~S}$ and COS concentrations are indeed nearly identical, suggesting that COS may be a primary source of total sulfide. However, near the shelf 
break, total sulfide concentrations are considerably greater than those of COS, and our atmospheric results indicate that air-sea fluxes may account for some of this "enrichment." Using the hydrolysis rate constants of Elliott et al. [1989], and 2-m-COS concentrations and temperatures along the shelf break, an average $\mathrm{H}_{2} \mathrm{~S}$ flux of $300 \mathrm{nmol} \mathrm{m}^{-2} \mathrm{~d}^{-1}(n=$ 7) from COS hydrolysis is calculated. In comparison, the atmospheric input flux in this region (Figure $4 b$ ) averages 210 nmol $\mathrm{m}^{-2} \mathrm{~d}^{-1}(n=8)$. Thus atmospheric input may be quantitatively as important as COS hydrolysis in contributing sulfide to the surface ocean in coastal regions adjacent to densely populated and polluted continental areas such as the eastern United States.

While our results show that, in the western North Atlantic region, deposition of continentally derived $\mathrm{H}_{2} \mathrm{~S}$ dominates over marine emissions, it still remains possible that $\mathrm{H}_{2} \mathrm{~S}$ may be emitted from the sea surface in open ocean areas. On the basis of our measured sulfide concentrations in North Atlantic seawater we can derive an upper limit for the global sea-to-air flux of $\mathrm{H}_{2} \mathrm{~S}$ by assuming a zero concentration of $\mathrm{H}_{2} \mathrm{~S}$ in the atmosphere over the ocean. The flux equation (6) then reduces to $F=K_{1} C_{\text {water }}$. Using the average undissociated $\mathrm{H}_{2} \mathrm{~S}$ concentration of $1.0 \mathrm{pmol} \mathrm{L}{ }^{-1}$ (from thermodynamic calculations using our data) and an average transfer coefficient $\left(K_{1}\right)$ of $276 \mathrm{~cm} \mathrm{~h}^{-1}$, we calculate an upper limit for the global flux of $0.28 \mathrm{Tg} \mathrm{S} \mathrm{yr}^{-1}$, which is substantially smaller than all previously established estimates of the global marine $\mathrm{H}_{2} \mathrm{~S}$ source, for example, the upper limits of 1 $\mathrm{Tg} \mathrm{S} \mathrm{yr}^{-1}$ [Saltzman and Cooper, 1988] and $3 \mathrm{Tg} \mathrm{yr}^{-1}$ suggested by Andreae [1990]. We conclude that even over remote ocean areas, $\mathrm{H}_{2} \mathrm{~S}$ is not likely to make a significant contribution to the atmospheric sulfur cycle.

Acknowledgments. We are grateful to the Captain and crew of the RV Cape Hatteras, who were most flexible and accommodating, and we thank B. Kluckhohn,'J. Guentzel, and R. Powell for their assistance during sampling and analysis at sea. We acknowledge $R$. Larson (Atmospheric Physics Branch, U.S. Naval Research Laboratories) for his generosity in letting us use the automated radon instrumentation. Thanks to R. Brost and U. Bartell for the calculations 'of back trajectories and meteorological interpretations, to I. Bambach and G. Feyerherd for preparation of the figures, and to $C$. Harris for editing of the mánuscript. Ship time and water column sulfide work were supported by NSF grant OCE-8800371 to G. Cutter.

\section{REFERENCES}

Andreae, M. O., The ocean as a source of atmospheric sulfur compounds, in The Role of Air-Sea Exchange in Geochemical Cycling, edited by P. Buat-Ménard, pp. 331-362, D. Reidel, Hingham, Mass., 1986.

Andreae, M. O., Ocean-atmosphere interactions in the global biogéochemical sulfur cycle, Mar. Chem., 30, 1-29, 1990.

Andreae, M. O., H. Berresheim, T. W. Andreae, M. A. Kritz, T. S. Bates, and J. T. Merrill, Vertical distribution of dimethylsulfide, sulfur dioxide, aerosol ions, and radon over the northeast Pacific Ocean, J. Atmos. Chem., 6, 149-173, 1988.

Balls, P. W., and P. S. Liss, Exchange of $\mathrm{H}_{2} \mathrm{~S}$ between water and air, Atmos. Environ., 17, 735-742, 1983.

Berresheim, H., M. O. Andreae, R. L. Iverson, and S. M. Li, Seasonal variations of atmospheric sulfur and nitrogen species over the western north Atlantic Ocean, Tellus, in press, 1991.

Bressan, D. J., R. E. Larson, and P. E. Wilkniss, Atmospheric radón and dust, air mass trajectories and meteorological conditions over the Greenland sea, Nature, 245, 74-78, 1973.

Broecker, W. S., and T.-H. Peng, Gas exchange rates between air and sea, Tellus, 26, 21-35, 1974.
Brost, R. A., and R. B. Chatfield, Transport of radon in a threedimensional, subhemispheric model, J. Geophys. Res., 94, 5095$5119,1989$.

Cooper, D. J., and E. S. Saltzman, Uptake of carbonyl sulfide by silver nitrate impregnated filters: Implications for the measurement of low level atmospheric $\mathrm{H}_{2} \mathrm{~S}$, Geophys. Res. Lett., 14, 206-209, 1987.

Cutter, G. A., and C. F. Krahforst, Sulfide in surface waters of the western Atlantic Ocean, Geophys. Res. Lett., 15, 1393-1396, 1988.

Cutter, G. A., and T. J. Oatts, Determination of dissolved sulfide and sedimentary sulfur speciation using gas chromatographyphotoionization detection, Anal. Chem., 59, 717-721, 1987.

Delmas, R., and J. Servant, The origins of sulfur compounds in the atmosphere of a zone of high productivity (Gulf of Guinea), $J$. Geophys. Res., 87, 11,019-11,026, 1982.

de Souza, T. L. C., D. C. Lane, and S. P. Bhatia, Analysis of sulfur-containing gases by gas-solid chromatography on a specially treated Porapak QS column packing, Anal. Chem., 47, 543-545, 1975.

Doerr, H., B. Kromer, I. Levin, K. O. Muennich, and H.-J. Volpp, $\mathrm{CO}_{2}$ and radon 222 as tracers for atmospheric transport, $J$. Geophys. Res., 88, 1309-1313, 1983.

Douabul, A. A., and J. P. Riley, The solubility of gases in distilled water and seawater, V, Hydrogen sulphide, Deep Sea Res., Part A, 26, 259-268, 1979.

Eigen, M., W. Kruse, G. Maas, and L. DeMaeyer, Rate constants of protolytic reactions in aqueous solution, Prog. React. Kinet., 2, 285-318, 1964.

Elliott, S., and F. S. Rowland, The effect of metal complexation on hydrogen sulfide transport across the sea-air interface, J. Atmos. Chem., 10, 315-327, 1990.

Elliott, S., E. Liu, and F. S. Rowland, Carbonyl sulfide hydrolysis as a source of hydrogen sulfide in open ocean seawater, Geophys. Res. Lett., 14, 131-134, 1987.

Elliott, S., E. Liu, and F. S. Rowland, Rates and mechanisms for the hydrolysis of carbonyl sulfide in natural waters, Environ. Sci. Technol., 23, 458-461, 1989.

Eriksson, E., The yearly circulation of sulfur in nature, J. Geophys. Res., 68, 4001-4008, 1963.

Friend, J. P., The global sulfur cycle, in Chemistry of the Lower Atmosphere, edited by S. I. Rasool, pp. 177-201, Plenum, New York, 1973.

Galloway, J. N., and D. M. Whelpdale, WATOX-86 overview and western North Atlantic Ocean $\mathbf{S}$ and $\mathbf{N}$ atmospheric budgets, Global Biogeochem. Cycles, 1, 261-281, 1287.

Graedel, T. E., Reduced sulfur emission from the open oceans, Geophys. Res. Lett., 6, 329-331, 1979.

Gregory, G. L., J. M. Hoell Jr., and D. D. Davis, Airborne sulfur trace species intercomparison compaign; Sulfur dioxide, dimethylsulfide, hydrogen sulfide, carbon disulfide, and carbonyl sulfide, Eos Trans. AGU, 74, 1254, 1990.

Herrmann, J., and W. Jaeschke, Measurements of $\mathrm{H}_{2} \mathrm{~S}$ and $\mathrm{SO}_{2}$ over the Atlantic Ocean, J. Atmos. Chem., 1, 111-123, 1984.

Hoover, T. E., and D. C. Berkshire, Effects of hydration on carbon dioxide exchange across an air-water interface, J. Geophys. Res., 74, 456-464, 1969.

Johnson, J. E., and H. Harrison, Carbonyl sulfide concentrations in the surface waters and above the Pacific Ocean, J. Geophys. Res., 91, 7883-7888, 1986.

Kellogg, W. W., R. D. Cadle, E. R. Allen, A. L. Lazrus, and E. A. Martell, The sulfur cycle, Science, 175, 587-596, 1972.

Lambert, G., G. Polian, J. Sanak, B. Ardouin, A. Buisson, A. Jegou, and J. C. LeRoulley, Radon and daughter products cycle: Application to trophosphere-stratosphere exchanges (in French), Ann. Geophys., 38, 497-531, 1982.

Larson, R. E., and D. J. Bressan, Radon-222 as an indicator of continental air masses and air mass boundaries over ocean areas, in Natural Radiation Environment III, edited by T.F. Gesell and W. M. Lowder, pp. 308-325, U.S. Department of Commerce, Springfield, Va., 1978a.

Larson, R. E., and D. J. Bressan, Automatic radon counter for continual unattended operation, Rev. Sci. Instrum., 49, 965 , $1978 b$.

Liss, P. S., and L. Merlivat, Air-sea gas exchange rates: Introduction and synthesis, in The Role of Air-Sea Exchange in Geochem- 
ical Cycling, edited by P. Buat-Ménard, pp. 113-127, D. Reidel, Hingham, Mass., 1986.

Liss, P. S., and P. G. Slater, Flux of gases across an air-water interface, Nature, 247, 181-184, 1974.

Luther, G. W., III, and E. Tsamakis, Concentration and form of dissolved sulfide in the oxic water column of the ocean, Mar. Chem., 27, 165-177, 1989.

Millero, F. J., and J. P. Hershey, Thermodynamics and kinetics of hydrogen sulfide in natural waters, in Biogenic Sulfur in the Environment, ACS Symp. Ser., edited by E. S. Saltzman and W. J. Cooper, pp. 282-313, American Chemical Society, Washington, D. C., 1989.

Mogro-campero, A., and R. L. Fleischer, Search for long-distance migration of subsurface radon, in Natural Radiation Environment III, edited by T. F. Gesell and W. M. Lowder, p. 72, U.S. Department of Commerce, Springfield, Va., 1978.

Natusch, D. F. S., H. B. Klonis, H. D. Axelrod, R. J. Teck, and J.. P. Lodge Jr., Sensitive method for measurement of atmospheric hydrogen sulfide, Anal. Chem., 44, 2067-2070, 1972.

Polian, G., G. Lambert, B. Ardouin, and A. Jegou, Long-range transport of continental radon in subantartic and antartic areas, Tellus, 38B, 178-189, 1986.

Robinson, E., and R. C. Robbins, Sources, gaseous sulfur pollutants from urban and natural sources, J. Air Pollut. Control Assoc., 20, 303-306, 1970.

Rodhe, H., and I. Isaksen, Global distribution of sulfur compounds in the troposphere estimated in a height/latitude transport model, J'.' Geophys. Res., 85, 7401-7409, 1980.

Saltzman, E. S., and D. J. Cooper, Shipboard measurements of atmospheric dimethylsulfide and hydrogen sulfide in the Caribbean and Gulf of Mexico, J. Atmos. Chem., 7, 191-209, 1988.

Saunders, A. W., R. L. Patterson, Jr., and L. B. Lockhart, Jr.,
Interaction of radon decay products with aerosols, Rep. 6802, Naval Res. Lab., Washington, D. C., 1968.

Slatt, B. J., D. F. S. Natusch, J. M. Prospero, and D. L. Savoie, Hydrogen sulfide in the atmosphere of the northern equatorial Atlantic ocean and its relation to the global sulfur cycle, Atmos. Environ., 12, 981-991, 1978.

Stumm, W., and J. J. Morgan, Aquatic Chemistry, 780 pp., John Wiley, New York, 1981

Sze, N. D., and M. F. W. Ko, Photochemistry of COS, $\mathrm{CS}_{2}$, $\mathrm{CH}_{3} \mathrm{SCH}_{3}$ and $\mathrm{H}_{2} \mathrm{~S}$ : Implications for the atmospheric sulfur cycle, Atmos. Environ., 14, 1223-1239, 1980.

Tanner, A. B., Radon migration in the ground: A supplementary review, in Natural Radiation Environment III, edited by T. F. Gesell and W. M. Lowder, p. 5, U.S. Department of Commerce, Springfield, Va., 1978.

Toon, O. B., J. F. Kasting, R. P. Turco, and M. S. Liu, The sulfur cycle in the marine atmosphere, J. Geophys. Res., , 92, 943-963, 1987.

T. W. Andreae and M. O. Andreae, Department of Biogeochemistry, Max Planck Institute for Chemistry, P. O. Box 3060, D-6500 Mainz, Federal Republic of Germany.

G. A. Cutter and J. Radford-Knoery, Department of Oceanography, Old Dominion University, Norfolk, VA 23529.

N. Hussain, College of Marine Studies, University of Delaware, Newark, DE 19716.

(Received December 7, 1990 revised June 17, 1991; accepted June 17, 1991.) 